Watching War 



\section{Watching War}

Jan Mieszkowski

Stanford University Press

Stanford, California 
Stanford University Press

Stanford, California

(C) 2012 by the Board of Trustees of the Leland Stanford Junior University. All rights reserved.

No part of this book may be reproduced or transmitted in any form or by any means, electronic or mechanical, including photocopying and recording, or in any information storage or retrieval system without the prior written permission of Stanford University Press.

Printed in the United States of America on acid-free, archival-quality paper.

Library of Congress Cataloging-in-Publication Data

Mieszkowski, Jan, author.

Watching war / Jan Mieszkowski.

pages $\mathrm{cm}$

Includes bibliographical references and index.

ISBN 978-0-8047-8239-5 (cloth : alk. paper) -

ISBN 978-0-8047-8240-I (pbk. : alk. paper)

I. War in literature. 2. War in mass media. 3. Mass mediaAudiences. I. Title.

$\mathrm{PN}_{5} 6 . \mathrm{W}_{3} \mathrm{M}_{54} 2 \mathrm{OI} 2$

$303.6609-\mathrm{dc} 23$

2012005968

Typeset by Westchester Book Group in I0.9/13 Adobe Garamond 
To Sarah 
